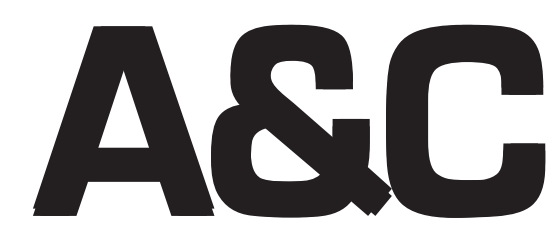

Revista de Direito Administrativo \& Constitucional

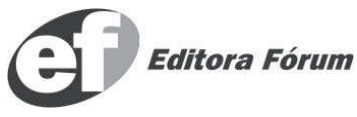

ISSN 1516-3210 


\section{A\&C REVISTA DE DIREITO ADMINISTRATIVO \& CONSTITUCIONAL}

\section{IPDA}

Instituto Paranaense

de Direito Administrativo

Direção Geral

Romeu Felipe Bacellar Filho

Direção Editorial

Paulo Roberto Ferreira Motta

Direção Executiva

Emerson Gabardo

Conselho de Redação

Edgar Chiuratto Guimarães

Adriana da Costa Ricardo Schier

Célio Heitor Guimarães

\section{Conselho Editorial}

Adilson Abreu Dallari (Brasil) Alice Gonzales Borges (Brasil) Antonello Tarzia (Itália)

Carlos Ari Sundfeld (Brasil)

Carlos Ayres Britto (Brasil)

Carlos Delpiazzo (Uruguai)

Cármen Lúcia Antunes Rocha (Brasil)

Celso Antônio Bandeira de Mello

(Brasil)

Clèmerson Merlin Clève (Brasil)

Clovis Beznos (Brasil)

Enrique Silva Cimma (Chile)

Eros Roberto Grau (Brasil)

Fabrício Motta (Brasil)

Guilhermo Andrés Muñoz - in memoriam

(Argentina)

Jaime Rodríguez-Arana Muñoz (Espanha)

Jorge Luís Salomoni - in memoriam
(Argentina)
José Carlos Abraão (Brasil)
José Eduardo Martins Cardoso (Brasil)
José Luís Said (Argentina)
José Mario Serrate Paz (Uruguai)
Juan Pablo Cajarville Peruffo (Uruguai)
Juarez Freitas (Brasil)
Julio Rodolfo Comadira - in memoriam
(Argentina)
Luís Enrique Chase Plate (Paraguai)
Lúcia Valle Figueiredo (Brasil)
Manoel de Oliveira Franco Sobrinho -
in memoriam (Brasil)
Marçal Justen Filho (Brasil)
Marcelo Figueiredo (Brasil)

\author{
Maria Cristina Cesar de Oliveira (Brasil) \\ Nelson Figueiredo (Brasil) \\ Odilon Borges Junior (Brasil) \\ Pascual Caiella (Argentina) \\ Paulo Eduardo Garrido Modesto (Brasil) \\ Paulo Henrique Blasi (Brasil) \\ Paulo Neves de Carvalho - in memoriam \\ (Brasil) \\ Paulo Ricardo Schier (Brasil) \\ Pedro Paulo de Almeida Dutra (Brasil) \\ Regina Maria Macedo Nery Ferrari (Brasil) \\ Rogério Gesta Leal (Brasil) \\ Rolando Pantoja Bauzá (Chile) \\ Sérgio Ferraz (Brasil) \\ Valmir Pontes Filho (Brasil) \\ Weida Zancaner (Brasil) \\ Yara Stropa (Brasil)
}

A246 A\&C Revista de Direito Administrativo \& Constitucional. ano 3, n. 11, jan./mar. 2003. Belo Horizonte: Fórum, 2003.

Trimestral

ano 1, n. 1, 1999 até ano 2, n. 10, 2002 publicada pela Editora Juruá em Curitiba

ISSN 1516-3210

1. Direito Administrativo. 2. Direito Constitucional. I. Fórum.

CDD: 342

CDU: 33.342

(C) 2008 Editora Fórum Ltda.

Todos os direitos reservados. É proibida a reprodução total ou parcial, de qualquer forma ou por qualquer meio eletrônico ou mecânico, inclusive através de processos xerográficos, de fotocópias ou de gravação, sem permissão por escrito do possuidor dos direitos de cópias (Lei nº 9.610, de 19.02.1998).

Editora Fórum Ltda

Editor responsável: Luís Cláudio Rodrigues Ferreira

Av. Afonso Pena, 2770 - 15\%16ªndar - Funcionários

CEP 30130-007 - Belo Horizonte/MG - Brasil

Coordenação editorial: Olga M. A. Sousa

Tel.: 08007043737

Internet: www.editoraforum.com.br

Pesquisa jurídica: Fátima Ribeiro - OAB/MG 74868

Revisora: Lourdes Nascimento

Projeto gráfico e diagramação: Luis Alberto Pimenta

e-mail: editoraforum@editoraforum.com.br

Bibliotecária: Fernanda de Paula Moreira - CRB 2900 - 6a região

Esta publicação está indexada no Ulrich's Periodicals Directory

Os conceitos e opiniões expressas nos trabalhos assinados são de responsabilidade exclusiva de seus autores.

Impressa no Brasil / Printed in Brazil

Distribuída em todo o Território Nacional 


\title{
O juiz em Pierre Bourdieu, o controle jurisdicional de políticas públicas no Brasil e a questão da liberdade de interpretação das normas jurídicas
}

\begin{abstract}
Thiago Cássio d'Ávila Araújo
Mestrando em Direito e Políticas Públicas no Centro Universitário de Brasília. Procurador Federal da Advocacia-Geral da União. Consultor Jurídico do Instituto Brasileiro de Turismo (EMBRATUR). Ex-Coordenador Nacional Substituto de Assuntos Jurídicos Administrativos da ProcuradoriaGeral do INCRA. Ex-Procurador do Instituto Nacional do Seguro Social (INSS). Ex-Procurador do Órgão de Arrecadação da Procuradoria-Geral Federal (OA/PGF).
\end{abstract}

\begin{abstract}
Resumo: O presente artigo aborda aspectos da jurisprudência de controle judicial de políticas públicas no Brasil, com objetivo teórico final de analisar, à luz da "Teoria do Campo Jurídico" de Pierre Bourdieu e da "Teoria Pura do Direito" de Hans Kelsen, a margem de liberdade dos juízes quanto à interpretação e aplicação das normas jurídicas.
\end{abstract}

Palavras-chave: Campo jurídico. Teoria Pura do Direito. Liberdade de interpretação e aplicação de normas jurídicas. Controle judicial de políticas públicas.

Sumário: 1 Introdução - 2 O campo jurídico e os juízes na visão de Bourdieu - 3 O controle judicial de políticas públicas: o discurso teórico - 4 O controle judicial de políticas públicas: o discurso judicial - 5 Haveria como ser diferente? - 6 Breve diálogo entre Bourdieu e Kelsen - 7 Conclusão - Referências

\section{Introdução ${ }^{1}$}

O sociólogo francês Pierre Bourdieu entende que "o campo judicial é o espaço social organizado no qual e pelo qual se opera a transmutação de um conflito directo entre partes directamente interessadas no debate juridicamente regulado entre profissionais". ${ }^{2}$ De fato, é inegável que o campo judicial compreende um conflito entre partes de interesses diretamente opostos, que, através de advogados, buscam uma decisão (judicial) solucionadora do conflito. ${ }^{3}$

\footnotetext{
O presente artigo foi escrito como trabalho de conclusão da disciplina "Políticas Públicas e o Papel do Estado",ministrada pelo Professor Doutor Frederico Augusto Barbosa da Silva no Mestrado em Direito e Políticas Públicas do Centro Universitário de Brasília (UniCEUB). A nota de rodapé n. 05 é sugestão do Professor Doutor Frederico Augusto Barbosa da Silva. A utilização do texto de Thiry-Cherques na nota de rodapé n. 16, que proporciona uma abordagem do conceito de habitus na obra de Bourdieu, é sugestão do Professor Doutor Gílson Ciarallo, pesquisador do grupo "Epistemologia e Tópicos Metodológicos" (que honrosamente integro), do UniCEUB. Agradeço a ambos, ainda, pela revisão metodológica de todo o texto. BOURDIEU. O poder simbólico, p. 229.

Entendemos que a posição de Bourdieu é correta ao menos no que se refere à "jurisdição contenciosa".
} 
Bourdieu oferece uma visão do poder dos juízes, ao analisar o "campo jurídico" e "a força do Direito", em sua obra internacionalmente famosa "O Poder Simbólico". Conforme veremos no decorrer do texto, Bourdieu identifica nos juízes um enorme poder, decorrente da elasticidade dos textos legais, que vão do indeterminado ao equívoco, e permitem aos juízes, pela via hermenêutica, a construção de decisões dentro de uma margem de "imensa liberdade". ${ }^{4}$

A abordagem dessa "imensa liberdade” dos juízes, quando da interpretação e aplicação dos textos legais, pode, evidentemente, ser realizada com diversos enfoques, seja em "sentido abstrato", numa espécie de teorização da ampla liberdade de decidir, seja em "sentido concreto", analisando-se, pelo método empírico, como os juízes se movem quando julgam determinado assunto.

No presente trabalho, optamos pela análise empírica da fundamentação dos juízes quando julgam questões referentes às políticas públicas. Para tanto, serão analisados alguns julgados.

Entretanto, entendemos que uma abordagem teórica preliminar é relevante, até mesmo para situarmos o pensamento de Bourdieu em relação à matéria. Assim, o presente trabalho se inicia com uma abordagem do "campo jurídico" e dos juízes na visão do sociólogo francês.

Ao final, será aberta uma proposta de diálogo entre Bourdieu e Hans Kelsen, para analisar a questão política da decisão judicial. ${ }^{5}$

\section{0 campo jurídico e os juízes na visão de Bourdieu}

Bourdieu concebe o campo jurídico como o lugar de concorrência pelo monopólio do direito de dizer o direito, quer dizer, a boa distribuição (nomos) ou a boa ordem, na qual se defrontam agentes investidos de competência ao mesmo tempo social e técnica que consiste essencialmente na capacidade reconhecida de interpretar (de maneira mais ou menos livre ou autorizada) um corpus de textos que consagram a visão legítima, justa, do mundo social.

Em Bourdieu, essa concorrência pelo monopólio do acesso aos meios jurídicos herdados do passado contribui para fundamentar a cisão social entre os profanos e os profissionais favorecendo um trabalho contínuo de racionalização próprio para aumentar cada vez mais o desvio entre os

4 BOURDIEU. O poder simbólico, p. 223.

5 Metodologicamente, foi feito um recorte do texto de Bourdieu, conferindo-lhe um caráter mais hermenêutico, enquanto que a Kelsen se atribuiu um caráter mais político. O diálogo é possível por aproximação.

A\&C R. de Dir. Administrativo \& Constitucional, Belo Horizonte, ano 8, n. 33, p. 135-160, jul./set. 2008 
vereditos armados do direito e as intuições ingênuas da equidade e para fazer com que o sistema das normas jurídicas apareça aos que o impõem e mesmo, em maior ou menor medida, aos que a ele estão sujeitos, como totalmente independente das relações de força que ele sanciona e consagra. ${ }^{6}$ Como bem assinala o Professor da Universidad Nacional de Colombia, Sr. William Jiménez Gil, "la lucha que opera en el campo jurídico no es la lucha por la eficacia o por la justicia, sino que opera con vista al monopolio por decir lo que es el derecho". ${ }^{7}$

Duas conseqüências se sobressaem em razão da existência de um campo jurídico: a primeira é a separação que o campo jurídico exerce entre profanos e profissionais; a segunda é o direcionamento prático da hermenêutica jurídica, que não é um fim em si mesma, ao contrário da hermenêutica literária ou filosófica. ${ }^{8}$

O primeiro aspecto está em que a maior parte dos processos lingüísticos característicos do campo jurídico concorrem, com efeito, para produzir dois efeitos maiores: o efeito de neutralização e o efeito de universalização.

Para Bourdieu, o efeito de neutralização é obtido por um conjunto de características sintáticas, tais como: predomínio das construções passivas e das frases impessoais, próprias para marcar a impersonalidade do enunciado normativo e para constituir o enunciador em sujeito universal, ao mesmo tempo imparcial e objetivo. Por sua vez, o efeito de universalização é obtido por meio de vários processos convergentes: o recurso sistemático ao indicativo para enunciar normas, o emprego de verbos atestativos na terceira pessoa do singular do presente ou do passado composto que exprimem o aspecto realizado ("aceita”, "confessa”, "compromete-se", declarou”, etc.), e assim por diante. ${ }^{9}$ Bourdieu, ainda em letras mais claras, exprime que esta retórica da autonomia, da neutralidade e da universalidade, que pode ser o princípio de uma autonomia real dos pensamentos e das práticas, está longe de ser uma simples máscara ideológica: é a própria expressão de todo o funcionamento do campo jurídico. ${ }^{10}$

Além do mais, a separação entre o profano e o profissional encerra em si mesma uma valorização deste último nas categorias sociais. Bourdieu

\footnotetext{
BOURDIEU. O poder simbólico, p. 212.

GIL. La teoria del campo juridico de Pierre Bourdieu: aplicación a un caso practico del Derecho Colombiano. Disponível em: <http://www.docentes.unal.edu.co/wjimenezg/>. Acesso em: 10 jun. 2008.

8 BOURDIEU. O poder simbólico, p. 212-213.

9 BOURDIEU. O poder simbólico, p. 215-216.

10 BOURDIEU. O poder simbólico, p. 215-216.
}

A\&C R. de Dir. Administrativo \& Constitucional, Belo Horizonte, ano 8, n. 33, p. 135-160, jul./set. 2008 
interpreta que o desvio entre a visão vulgar daquele que se vai tornar um “justiciável”, quer dizer, um cliente, e a visão científica do perito, juiz, advogado, conselheiro jurídico, etc., nada tem de acidental: é constitutivo de uma relação de poder. ${ }^{11}$

Essa separação entre profanos e profissionais do Direito, que tão bem caracteriza o "campo jurídico", foi muito bem retratada na literatura por Franz Kafka. ${ }^{12}$ Como apontado por Belo et al.:

Josef K. é processado e não sabe o motivo; não tem acesso ao seu processo; o tribunal e seus membros, inclusive seu advogado, lhe parecem inacessíveis. A estória de Josef K. mostra como o campo jurídico pode ser transformado numa instituição cujas regras só são compreendidas por alguns, deixando de fora o próprio sujeito que convoca ou é convocado pelo Direito. ${ }^{13}$

O segundo aspecto está em que, na visão de Bourdieu, por mais que os juristas possam opor-se a respeito de textos cujo sentido nunca se impõe de maneira absolutamente imperativa, eles permanecem inseridos num corpo fortemente integrado de instâncias hierarquizadas que estão à altura de resolver os conflitos entre os intérpretes e as interpretações. Assim, a justiça organiza segundo uma estrita hierarquia não só as instâncias judiciais e os seus poderes, portanto, as suas decisões e as interpretações em que elas se apóiam, mas também as normas e as fontes que conferem a sua autoridade a essas decisões. ${ }^{14}$

De fato, a observação de Bourdieu é pertinente. Veja-se, por exemplo, que o dispositivo constitucional constante do art. $5^{\circ}$, inciso XXXVII, "não haverá juízo ou tribunal de exceção", bem como a outra garantia fundamental do art. $5^{\circ}$, inciso LIII, "ninguém será processado nem sentenciado senão pela autoridade competente", aparecem como proteção aos indivíduos, a ponto de Athos Gusmão Carneiro escrever que "a jurisdição somente pode ser exercida por pessoa legalmente investida no poder de julgar, como integrante de algum dos órgãos do Poder Judiciário", ${ }^{15}$ mas esconde-se que do outro lado da moeda está o monopólio do Judiciário em julgar pessoas e relações jurídicas. Ou seja, o monopólio de dizer o Direito, como quer Bourdieu.

\footnotetext{
BOURDIEU. O poder simbólico, p. 226

12 KAFKA. O processo.

13 BELO; LASMAR; RODRIGUES. O inacessível campo jurídico: breve leitura de o processo, de Kafka, a partir da teoria de Pierre Bourdieu. Disponível em: <http://conpedi.org/manaus>. Acesso em: $1^{\circ}$ jun. 2008.

14 BOURDIEU. O poder simbólico, p. 213-214.

15 CARNEIRO. Jurisdição e competência, p. 11.
}

A\&C R. de Dir. Administrativo \& Constitucional, Belo Horizonte, ano 8, n. 33, p. 135-160, jul./set. 2008 
Esse poder de dizer o direito de que estão imbuídos os juízes é geralmente exposto sob um aspecto de distanciamento, que conduz à imagem de sabedoria e imparcialidade. Bourdieu a chama de "distância neutralizante", complementando que a mesma, "no caso dos magistrados pelo menos, é uma espécie de imperativo da função que está inscrita no âmago dos habitus". ${ }^{16}$

No entanto, Bourdieu não acredita neste distanciamento como sendo algo real. Afirma que "é difícil crer que as construções mais puras do jurista, sem mesmo falar dos atos de jurisprudência do juiz ordinário, obedeçam à lógica dedutivista que é o 'ponto de honra espirirualista' do jurista profissional". ${ }^{17}$ Para Bourdieu:

(...) os "realistas" bem mostraram que é completamente vão procurar isolar uma metodologia jurídica perfeitamente racional, porque a aplicação necessária de uma regra de direito a um caso particular é na realidade uma confrontação de direitos antagonistas entre os quais o Tribunal deve escolher. Ou seja, a "regra" tirada de um caso precedente nunca pode ser pura e simplesmente aplicada a um novo caso, porque não há nunca dois casos perfeitamente idênticos, hipótese em que deve o juiz determinar se a regra aplicada ao primeiro caso pode ou não ser estendida de maneira a incluir o novo caso. ${ }^{18}$

Ou seja, em outras palavras, e de maneira mais clara, o que Bourdieu quer dizer é que "o juiz, ao invés de ser sempre um simples executante que deduzisse da lei as conclusões directamente aplicáveis ao caso particular, dispõe antes de uma parte de autonomia"19 - o que seria a melhor medida da sua posição na estrutura da distribuição do capital específico de autoridade jurídica. Para Bourdieu, os juízos formulados pelos juízes na apreciação do caso concreto se inspiram numa lógica e em valores muito próximos dos que estão nos textos submetidos à sua interpretação, verificando-se uma verdadeira "função de invenção". ${ }^{20}$ Ou seja, Bourdieu

\footnotetext{
${ }^{16}$ BOURDIEU. O poder simbólico, p. 227. A noção de habitus é bem retratada por Hermano Roberto ThiryCherques, verbis: "Ele contém em si o conhecimento e o reconhecimento das/regras do jogo/ em um campo determinado. O habitus funciona como esquema de ação, de percepção, de reflexão. Presente no corpo (gestos, posturas) e na mente (formas de ver, de classificar) da coletividade inscrita em um campo, automatiza as escolhas e as ações em um campo dado, 'economiza' o cálculo e a reflexão. O habitus é o produto da experiência biográfica individual, da experiência histórica coletiva e da interação entre essas experiências. Uma espécie de programa, no sentido da informática, que todos nós carregamos". RAP, Rio de Janeiro, v. 40, n. 1, p. 34, jan./fev. 2006. Disponível em: <http://www.scielo.br/pdf/rap/v40n1/v40n1a03.pdf>. Acesso em: 12 jun. 2008

17 BOURDIEU. O poder simbólico, p. 222.

18 BOURDIEU. O poder simbólico, p. 222.

19 BOURDIEU. O poder simbólico, p. 222.

20 BOURDIEU. O poder simbólico, p. 222-223.
}

A\&C R. de Dir. Administrativo \& Constitucional, Belo Horizonte, ano 8, n. 33, p. 135-160, jul./set. 2008 
entende que ainda que as regras escritas tragam consigo a tendência de reduzir a variabilidade comportamental, não há dúvida também de que as condutas dos agentes jurídicos podem referir-se e sujeitar-se mais ou menos estritamente às exigências da lei, ficando sempre uma parte de arbitrário. ${ }^{21}$ Desta maneira:

A interpretação opera a historicização da norma, adaptando as fontes a circunstâncias novas, descobrindo nelas possibilidades inéditas, deixando de lado o que está ultrapassado ou o que é caduco. Dada a extraordinária elasticidade dos textos, que vão por vezes até à indeterminação ou ao equívoco, a operação hermenêutica de declaratio dispõe de uma imensa liberdade. ${ }^{22}$

"Imensa liberdade"! Bourdieu, ao que tudo indica, atribui à linguagem e seus usos o poder elástico dos juízes, mas jamais desconsiderando a influência exercida pelos argumentos dos advogados das partes. Entende que os juristas e os juízes dispõem todos, embora em graus muito diferentes, do poder de explorar a polissemia ou a anfibologia das fórmulas jurídicas recorrendo (i) quer à restrictio, processo necessário para se não aplicar uma lei que, entendida literalmente, o deveria ser, (ii) quer à extensio, processo que permite que se aplique uma lei que, tomada à letra, não o deveria ser, (iii) quer ainda a todas as técnicas que, como a analogia, tendem a tirar o máximo partido da elasticidade da lei e mesmo das suas contradições, das suas ambigüidades ou das suas lacunas. ${ }^{23}$ Leia-se mais:

O trabalho de racionalização, ao fazer aceder ao estatuto de veredicto uma decisão judicial que deve, sem dúvida, mais às atitudes éticas dos agentes do que às normas puras do direito, confere-lhe a eficácia simbólica exercida por toda a acção quando, ignorada no que têm de arbitrário, é reconhecida como legítima. O princípio desta eficácia reside, pelo menos em parte, em que, salvo vigilância especial, a impressão de necessidade lógica sugerida pela forma tende a contaminar o conteúdo. O formalismo racional ou racionalizante do direito racional, que se tende a opor, com Weber, ao formalismo mágico dos rituais e dos procedimentos arcaicos de julgamento (como o juramento individual ou colectivo), participa na eficácia simbólica do direito mais racional. E o ritual destinado a enaltecer a autoridade do acto de interpretação - leitura dos textos, análise e proclamação das conclusões, etc. - ao qual, desde Pascal, a análise se agarra, não faz mais do que acompanhar todo o trabalho colectivo

\footnotetext{
21 BOURDIEU. O poder simbólico, p. 223

22 BOURDIEU. O poder simbólico, p. 223

23 BOURDIEU. O poder simbólico, p. 224-225. Observamos que a Lei de Introdução ao Código Civil brasileiro (LICC - Decreto-Lei n 4.657, de 4 de setembro de 1942) dispõe que, quando a lei for omissa, o juiz decidirá o caso de acordo com a analogia, os costumes e os princípios gerais de direito (art. $4^{\circ}$ ) e que, na aplicação da lei, o juiz atenderá aos fins sociais a que ela se dirige e às exigências do bem comum (art. $5^{\circ}$ ).
}

A\&C R. de Dir. Administrativo \& Constitucional, Belo Horizonte, ano 8, n. 33, p. 135-160, jul./set. 2008 
de sublimação destinado a atestar que a decisão exprime não a vontade e a visão do mundo do juiz, mas sim a voluntas legis ou legislatoris. ${ }^{24}$

Vê-se, portanto, que Bourdieu não acredita numa verdade objetiva da lei (voluntas legis ou legislatoris), mas antes numa vontade do juiz, que todavia, sublimada pelo ritual do julgamento, parece ser uma interpretação neutra do texto normativo.

\section{O controle judicial de políticas públicas: o discurso teórico}

O esboço teórico acima relatado (noções de campo jurídico e habitus na obra de Bourdieu) nos servirá no momento de encararmos, empiricamente, a construção argumentativa dos juízes, no ato de decidir matérias de políticas públicas.

Antes, porém, de abordarmos o aspecto jurisprudencial, e entendermos porque Bourdieu foi chamado ao presente texto, é pertinente que abordemos o aspecto teórico do controle judicial de políticas públicas. Conhecer o que diz a "doutrina" jurídica é fundamental para analisar-se sua interação com a ordem judicial e o plano prático-decisório do campo jurídico. Mais à frente tornar-se-á mais compreensível nossa proposta.

O controle judicial de políticas públicas ocorre no Brasil de forma cada vez mais freqüente. A noção de separação dos poderes (Constituição, 1988, art. $2^{\circ}$ ), independentes e harmônicos entre si, que reservaria, ao menos em tese, aos Poderes Executivo e Legislativo a formulação de políticas públicas, cada vez mais vem sendo desgastada pelo aumento de decisões judiciais, país afora, que interferem em políticas públicas, fazendo do Poder Judiciário um importante ator nas práticas governamentais.

Como bem observado por Marcus Aurélio de Freitas Barros:

(...) tal ótica tem sido percebida até por parlamentares, em especial os integrantes das minorias políticas, haja vista seu protagonismo na utilização das ações constitucionais. As minorias participantes do poder, cada vez mais, têm se socorrido do Poder Judiciário para questionar decisões políticas importantes. Estas se valem do procedimento judicial para uma inserção mais destacada no contexto político. ${ }^{25}$

Ou seja, estaria ocorrendo uma verdadeira "judicialização da política".

\footnotetext{
24 BOURDIEU. O poder simbólico, p. 224-225.

25 BARROS. Miradas sobre o controle jurisdicional de políticas públicas: dos precedentes judiciais à teoria. Disponível em: <http://sisnet.aduaneiras.com.br/lex/doutrinas/arquivos/miradas.pdf > . Acesso em: $1^{\circ}$ jun. 2008.
}

A\&C R. de Dir. Administrativo \& Constitucional, Belo Horizonte, ano 8, n. 33, p. 135-160, jul./set. 2008 
Em razão da Constituição Federal de 1988 (art. 129), ampliou-se enormemente o rol de atribuições do Ministério Público, destacando-se, entre suas várias funções institucionais, "zelar pelo efetivo respeito dos Poderes Públicos e dos serviços de relevância pública aos direitos assegurados nesta Constituição, promovendo as medidas necessárias a sua garantia", "promover o inquérito civil e a ação civil pública, para a proteção do patrimônio público e social, do meio ambiente e de outros interesses difusos e coletivos" (como o direito ao ambiente ecologicamente equilibrado, etc.), além de "exercer outras funções que lhe forem conferidas por lei, desde que compatíveis com sua finalidade".

Cumpre dizer, portanto, que admitir a possibilidade jurídica de controle judicial de políticas públicas interessa sobremaneira aos membros do Ministério Público, que ingressam rotineiramente com ações judiciais para que governos e burocratas cumpram políticas públicas na forma em que se pleiteia nas ações judiciais. Com efeito, se o Judiciário, em autolimitação, se julgasse impossibilitado de intervir em políticas públicas, os membros do Ministério Público perderiam em poder (referente ao poder de provocar a Justiça, pela propositura da ação em casos tais, que seria extinta sem julgamento de mérito por impossibilidade jurídica do pedido; e poder de influência política no andamento do Estado). Assim é que se torna possível encontrar muitos textos escritos por membros do Ministério Público, defendendo, do ponto de vista teórico, à quase unanimidade, a possibilidade de intervenção judicial em políticas públicas.

O discurso em favor da possibilidade de intervenção judicial em políticas públicas fundamenta-se, primordialmente, em quatro bases argumentativas:

a) princípio da supremacia da Constituição;

b) princípio da máxima efetividade da Constituição;

c) efetivação de direitos fundamentais;

d) princípio constitucional da legalidade.

A supremacia da Constituição é um princípio jurídico central nos países que adotam sistema constitucional rígido, ou seja, um sistema jurídico em que normas infraconstitucionais não podem revogar normas constitucionais; em tais regimes, se a norma infraconstitucional for contrária à norma constitucional, será nula, já que hierarquicamente inferior à Constituição, merecendo ser declarada inconstitucional pelo controle jurisdicional de constitucionalidade. Ou, em outras palavras, nos ensinamentos de

A\&C R. de Dir. Administrativo \& Constitucional, Belo Horizonte, ano 8, n. 33, p. 135-160, jul./set. 2008 
Kildare Gonçalves Carvalho a respeito da classificação das Constituições quanto ao processo de reforma, "Rígidas são as que demandam um processo especial, mais solene e difícil para sua alteração do que o da formação das leis ordinárias. Flexíveis são as que podem ser alteradas pelo mesmo processo pelo qual se elaboram as leis ordinárias". ${ }^{26}$

Numa abordagem mais completa a respeito do princípio da supremacia da Constituição sob aspecto formal e material, escreve Guilherme Peña de Moraes:

O princípio da supremacia constitucional denota que a Constituição veicula as normas jurídicas de máxima hierarquia no sistema de Direito Positivo, figurando como fundamento de validade de todo ordenamento normativo.

Acentue-se que a supremacia, sob os aspectos de forma e de matéria, é decomposta em supremacia formal e supremacia material. De um lado, a supremacia formal induz a relação de hierarquia entre a Constituição e as demais espécies normativas, eis que a primeira é produzida pelo poder constituinte originário, ao passo que as segundas são produzidas pelos poderes constituídos, sendo aquele qualificado como anterior e superior em face destes. De outro lado, a supremacia material indica a maior importância das normas constitucionais, já que a estrutura fundamental do Estado é delineada na Lex Legum. .

Com relação ao princípio da máxima efetividade da Constituição, escreve o jurista português José Joaquim Gomes Canotilho:

Este princípio, também designado por princípio da eficiência ou princípio da interpretação efetiva, pode ser formulado da seguinte maneira: a uma norma constitucional deve ser atribuído o sentido que maior eficácia lhe dê. É um princípio operativo em relação a todas e quaisquer normas constitucionais, e embora a sua origem esteja ligada à tese da atualidade das normas programáticas (Thoma) é hoje sobretudo invocado no âmbito dos direitos fundamentais (no caso de dúvidas deve preferir-se a interpretação que reconheça maior eficácia aos direitos fundamentais). ${ }^{28}$ (Grifo nosso)

Como conseqüência dos princípios da supremacia da Constituição, que deve orientar as políticas públicas num Estado de Direito (discurso teórico), e da máxima efetividade da Constituição, que privilegia a interpretação favorável à maior eficácia possível aos direitos fundamentais, é que surge, como elemento central das decisões judiciais referentes às

\footnotetext{
${ }^{26}$ CARVALHO. Direito constitucional: teoria do Estado e da Constituição, p. 196.

27 MORAES. Direito constitucional: teoria da Constituição, p. 130.

${ }^{28}$ CANOTILHO. Direito constitucional, p. 162.
}

A\&C R. de Dir. Administrativo \& Constitucional, Belo Horizonte, ano 8, n. 33, p. 135-160, jul./set. 2008 
políticas públicas, a preocupação com a efetivação de direitos fundamentais. Note-se bem: o argumento da efetivação dos direitos fundamentais é que legitima, no campo teórico-constitucional, a intervenção judicial em matéria de políticas públicas.

O princípio constitucional da legalidade, por sua vez, vem consagrado no art. 37, caput, da Constituição Federal de 1988, de maneira que a Administração Pública só pode agir dentro do que prescrito em lei, e deve agir obedecendo aos ditames da lei. Assim é que, no aspecto teórico, se defende que a Administração deve atuar para cumprir direitos dos indivíduos que estejam prescritos em lei, como o direito à saúde, educação, etc., muito embora, também no plano teórico, vários sejam os textos que afirmem que, em se tratando de direitos fundamentais sociais, o cumprimento da lei se subjuga ao princípio da reserva do possível.

Não obstante o princípio da legalidade seja constitucional, geralmente a menção às próprias leis infraconstitucionais é que serve de fundamento às decisões judiciais para intervenção em políticas públicas. Nesses casos, se poderia também dizer que a legislação ordinária é que legitima, no campo teórico-infraconstitucional, a intervenção judicial em matéria de políticas públicas, sob a "proteção" do princípio constitucional da legalidade.

No entanto, para permitir-se a intervenção judicial em políticas públicas, essa conjugação teórica basilar de teor constitucionalista, acima explicada, alia-se a duas outras, de caráter mais operacional. A primeira, típica do direito administrativo, é a teoria da possibilidade de controle judicial de atos administrativos discricionários, aqueles em que há margem de liberdade do administrador público quanto ao mérito (conveniência e oportunidade) da decisão, mas que alguns juristas vêm considerando ser sujeito a controle jurisdicional em alguns casos. A segunda é a instrumentalização processual, que se dá principalmente pelo aspecto teórico da tutela jurisdicional de interesses difusos e coletivos, que se opera através de ações judiciais destinadas a tal, sendo mais comuns a ação popular, que pode ser ajuizada por qualquer cidadão, ou seja, eleitor, ${ }^{29}$ para anular ato lesivo ao patrimônio público ou de entidade de que o Estado participe, à moralidade administrativa, ao meio ambiente e ao patrimônio histórico e cultural, e a ação

\footnotetext{
${ }^{29}$ CF/88, art. 50, inc. LXXIII: "qualquer cidadão é parte legítima para propor ação popular que vise a anular ato lesivo ao patrimônio público ou de entidade de que o Estado participe, à moralidade administrativa, ao meio ambiente e ao patrimônio histórico e cultural, ficando o autor, salvo comprovada má-fé, isento de custas judiciais e do ônus da sucumbência".
}

A\&C R. de Dir. Administrativo \& Constitucional, Belo Horizonte, ano 8, n. 33, p. 135-160, jul./set. 2008 
civil pública, com seu amplo rol de legitimados, que contempla o Ministério Público, a Defensoria Pública, a União, os Estados, o Distrito Federal e os Municípios, as autarquias, empresas públicas, fundações ou sociedades de economia mista e, no que mais nos interessa, as associações que preencham os requisitos da Lei Federal $n^{\circ}$ 7.347, de 1985, com modificações da Lei Federal no 11.448 , de 2007.

\section{O controle judicial de políticas públicas: o discurso judicial}

O discurso teórico auxilia o discurso judicial?

O Superior Tribunal de Justiça (STJ), em julgamento realizado no ano 2000, assim se pronunciou:

O juiz não pode substituir a Administração Pública no exercício do poder discricionário. Assim, fica a cargo do Executivo a verificação da conveniência e da oportunidade de serem realizados atos de administração, tais como, a compra de ambulâncias e de obras de reforma de hospital público. O princípio da harmonia e independência entre os poderes há de ser observado, ainda que, em tese, em ação civil pública, possa o Município ser condenado à obrigação de fazer. ${ }^{30}$

No entanto, em vários outros julgados, mais recentes, o mesmo STJ vem admitindo a intervenção judicial. Exemplificativamente, no Recurso Especial (RESP) n ${ }^{\circ}$ 510598/SP, a decisão considerou o seguinte:

1. O Estatuto da Criança e do Adolescente (Lei n. 8.069/90) e a Lei de Diretrizes e Bases da Educação (Lei n. 9.394/96, art. 4º IV) asseguram o atendimento de crianças de zero a seis anos em creches e pré-escolas da rede pública. 2. Compete à Administração Pública propiciar às crianças de zero a seis anos acesso ao atendimento público educacional e a freqüência em creches, de forma que, estando jungida ao princípio da legalidade, é seu dever assegurar que tais serviços sejam prestados mediante rede própria. 3. (...) 4. A consideração de superlotação nas creches e de descumprimento da Lei Orçamentária Municipal deve ser comprovada pelo Município para que seja possível ao órgão julgador proferir decisão equilibrada na busca da conciliação entre o dever de prestar do ente público, suas reais possibilidades e as necessidades, sempre crescentes, da população na demanda por vagas no ensino pré-escolar. 5. No caso específico dos autos, não obstante tenha a municipalidade alegado falta de vagas e aplicação in totum dos recursos orçamentários destinados ao ensino fundamental, nada provou; a questão manteve-se no campo das possibilidades. Por certo que, em se tratando de caso concreto no qual estão envolvidas apenas

\footnotetext{
${ }^{30}$ STJ-2ª Turma, REsp 252.083, Rel. Min. Nancy Andrighi, unânime, j. 31.05.2000, DJ, 26 mar. 2001.
}

A\&C R. de Dir. Administrativo \& Constitucional, Belo Horizonte, ano 8, n. 33, p. 135-160, jul./set. 2008 
duas crianças, não haverá superlotação de nenhuma creche.${ }^{31} 6$. Recurso especial provido. ${ }^{32}$

Em outro caso envolvendo também o direito à creche extensivo aos menores de zero a seis anos, o STJ assim se pronunciou (observe-se, nesse julgado, o apelo a um direito constitucional fundamental, qual seja, direito à educação, a obediência ao princípio da legalidade, à possibilidade de controle de políticas públicas pelo Judiciário na existência de lei, e a rejeição dos argumentos orçamentário e de interferência desarmoniosa no Poder Executivo):

6. O direito à educação, insculpido na Constituição Federal e no Estatuto da Criança e do Adolescente, é direito indisponível, em função do bem comum, maior a proteger, derivado da própria força impositiva dos preceitos de ordem pública que regulam a matéria. (...) 15. As meras diretrizes traçadas pelas políticas públicas não são ainda direitos senão promessas de lege ferenda, encartando-se na esfera insindicável pelo Poder Judiciário, qual a da oportunidade de sua implementação. 16. Diversa é a hipótese segundo a qual a Constituição Federal consagra um direito e a norma infraconstitucional o explicita, impondo-se ao judiciário torná-lo realidade, ainda que para isso, resulte obrigação de fazer, com repercussão na esfera orçamentária. 17. Ressoa evidente que toda imposição jurisdicional à Fazenda Pública implica em dispêndio e atuar, sem que isso infrinja a harmonia dos poderes, porquanto no regime democrático e no estado de direito o Estado soberano submete-se à própria justiça que instituiu. Afastada, assim, a ingerência entre os poderes, o judiciário, alegado o malferimento da lei, nada mais fez do que cumpri-la ao determinar a realização prática da promessa constitucional. ${ }^{33}$

Analisemos mais decisões.

O critério jurisprudencial para efetivação do direito constitucional à saúde fica muito bem demonstrado neste acórdão do Tribunal Regional Federal da Primeira Região, em que se entendeu que "o rigor dos dispositivos legais que tratam do assunto há que ser mitigado em face da possibilidade da ocorrência de danos advindos da ausência do medicamento em questão". ${ }^{34}$

\footnotetext{
31 Percebe-se nessa parte da ementa o "poder de nomeação" a que se refere Bourdieu.

32 REsp 510598/SP - Recurso Especial - 2003/0003273-3 - Relator: Ministro João Otávio de Noronha - Órgão Julgador: T2 - Segunda Turma - Data do Julgamento: 17.04.2007 - Data da Publicação/Fonte: DJ, p. 148, 13 fev. 2008.

33 REsp 736524 / SP - Recurso Especial - 2005/0044941-4- Relator: Ministro Luiz Fux- Órgão Julgador: T1 Primeira Turma - Data do Julgamento: 21.03.2006 - Data da Publicação/Fonte: DJ, p. 256, 03 abr. 2006.

34 Processo: AGA 2007.01.00.010045-1/Pl; Agravo Regimental no Agravo de Instrumento - Relator: Desembargadora Federal Selene Maria de Almeida - Órgão Julgador: Quinta Turma - Publicação: 09 out. 2007, DJ, p. 172 - Data da Decisão: 18.07.2007.
}

A\&C R. de Dir. Administrativo \& Constitucional, Belo Horizonte, ano 8, n. 33, p. 135-160, jul./set. 2008 
Se caminharmos em direção à jurisprudência do Supremo Tribunal Federal, órgão jurisdicional a que compete precipuamente a interpretação da Constituição, a posição dominante atual é no sentido da judicialização das políticas públicas. Analisaremos, para meros fins analíticos, a jurisprudência do STF em relação à política pública de fornecimento gratuito de medicamentos.

No ano de 1999, em julgamento de 29 de junho, o então Ministro Ilmar Galvão não conheceu de recurso interposto pelo Estado do Rio Grande do Sul em matéria de medicamentos para doente portadora do vírus HIV contra decisão que teve por fundamento central dispositivo de lei (art. $1^{\circ}$ da Lei $n^{\circ} 9.908 / 93$ ) por meio da qual o próprio Estado do Rio Grande do Sul, regulamentando a norma do art. 196 da Constituição Federal, vinculou-se a um programa de distribuição de medicamentos a pessoas carentes. ${ }^{35}$ Posteriormente, em julgamento de 16.11.1999, que teve como relator o Ministro Marco Aurélio, decidiu-se:

O preceito do artigo 196 da Constituição Federal assegura aos necessitados o fornecimento, pelo Estado, dos medicamentos indispensáveis ao restabelecimento da saúde, especialmente quando em jogo doença contagiosa como é a Síndrome da Imunodeficiência Adquirida. ${ }^{36}$

No ano seguinte, em 22.02.2000, a Segunda Turma do STF apreciou feito sobre a obrigatoriedade do Estado fornecer medicamentos mesmo para doenças raras (no caso, fenilcetonúria). Observe-se que o medicamento, à época do julgamento, era fabricado apenas nos Estados Unidos da América e na Suíça. Apesar de não ter conhecido do recurso extraordinário (por razões processuais, como matéria fática e aplicação de lei local), o relator, Ministro Marco Aurélio, avançou com relevantes fundamentos jurisprudenciais. Eis parte da ementa:

SAÚDE - AQUISIÇÃO E FORNECIMENTO DE MEDICAMENTOS DOENÇA RARA. Incumbe ao Estado (gênero) proporcionar meios visando a

\footnotetext{
35 RE 242859/RS - Rio Grande do Sul - Recurso Extraordinário - Relator(a): Min. Ilmar Galvão - Julgamento: 29.06.1999 - Órgão Julgador: Primeira Turma - Publicação: DJ, 17 set. 1999 - Recte.: Estado do Rio Grande do Sul - Advdos.: PGE-RS - Kátia Elisabeth Wawrick e outros - Recdo.: Município de Porto Alegre - Advda.: Candida Silveira Saibert - Recda.: Rute Regina Serissol Nunes - Advdos.: Rosa Maria Rodrigues de Oliveira e outros. No mesmo sentido: RE 256327/RS - Rio Grande do Sul.

36 Al-AgR 238328/RS - Rio Grande do Sul - Ag. Reg. no Agravo de Instrumento - Relator(a): Min. Marco Aurélio - Julgamento: 16.11.1999 - Órgão Julgador: Segunda Turma - Publicação: DJ, 18 fev. 2000 - Agte.: Município de Porto Alegre - Advda.: Ana Luisa Soares de Carvalho - Agdo.: Carlos Fernando Becker - Advdos.: Márcia Elisa da Costa Abreu e outros.
}

A\&C R. de Dir. Administrativo \& Constitucional, Belo Horizonte, ano 8, n. 33, p. 135-160, jul./set. 2008 
alcançar a saúde, especialmente quando envolvida criança e adolescente. O Sistema Único de Saúde torna a responsabilidade linear alcançando a União, os Estados, o Distrito Federal e os Municípios. ${ }^{37}$

Observe-se que o STF interpretou, então, que a expressão "Estado" que consta no art. 196 da Constituição é gênero, englobando todas as unidades federadas..$^{38}$ Além disso, em seu voto, o Min. Marco Aurélio deixou expresso: "O Estado deve assumir as funções que lhe são próprias, sendo certo, ainda, que problemas orçamentários não podem obstaculizar o implemento do que previsto constitucionalmente". ${ }^{39}$

Em 12.09.2000, a Segunda Turma do STF julgou mais um caso sobre medicamentos, desta vez sob a relatoria do Min. Celso de Mello, onde se percebe um pronunciamento mais incisivo, de extensa fundamentação em favor do direito fundamental à saúde, em face da programação de políticas públicas de medicamentos pelo Estado-Administração (no caso, decidiase sobre fornecimento de medicamentos a paciente do vírus HIV). ${ }^{40}$ Assim, da ementa do acórdão de julgamento do RE-AgR 271286/RS são extraídos os seguintes fundamentos:

a) $O$ direito à saúde representa conseqüência constitucional indissociável do direito à vida: $\mathrm{O}$ direito público subjetivo à saúde representa prerrogativa jurídica indisponível assegurada à generalidade das pessoas pela própria Constituição da República (art. 196). Traduz bem jurídico constitucionalmente tutelado, por cuja integridade deve velar, de maneira responsável, o Poder Público, a quem incumbe formular — e implementar — políticas sociais e econômicas idôneas que visem a garantir, aos cidadãos, inclusive

\footnotetext{
37 RE 195192/RS - Rio Grande do Sul - Recurso Extraordinário - Relator: Min. Marco Aurélio - Julgamento: 22.02.2000 - Órgão Julgador: Segunda Turma - Publicação: DJ, 31 mar. 2000 - Recte.: Estado do Rio Grande do Sul - Recdo.: Rodrigo Skrsypcsak.

38 Eis a redação do dispositivo constitucional: "Art. 196. A saúde é direito de todos e dever do Estado, garantido mediante políticas sociais e econômicas que visem à redução do risco de doença e de outros agravos e ao acesso universal e igualitário às ações e serviços para sua promoção, proteção e recuperação".

39 RE 195192/RS - Rio Grande do Sul - Recurso Extraordinário - Relator: Min. Marco Aurélio - Julgamento: 22.02.2000 - Órgão Julgador: Segunda Turma - Publicação: DJ, 31 mar. 2000 - Recte.: Estado do Rio Grande do Sul - Recdo.: Rodrigo Skrsypcsak.

40 Advertimos que o que se discutia no feito eram questões processuais, em razão de que o Min. Celso de Mello anteriormente não havia conhecido de recurso extraordinário deduzido pelo Município de Porto Alegre. Apesar de a questão envolvida ser meramente processual, percebe-se que a ementa do acórdão avançou sobre o mérito constitucional do dever solidário dos entes políticos (entes federados) do Estado brasileiro em fornecer medicamentos a pessoas doentes e carentes economicamente. Referimo-nos ao REAgR 271286/RS - Rio Grande do Sul - Ag. Reg. no Recurso Extraordinário - Relator(a): Min. Celso de Mello - Julgamento: 12.09.2000 - Órgão Julgador: Segunda Turma - Publicação: DJ, 24 nov. 2000 - Agte.: Município de Porto Alegre - Advda.: Candida Silveira Saibert - Agda.: Diná Rosa Vieira - Advdos.: Eduardo von Mühlen e outros - Advdos.: Luís Maximiliano Leal Telesca Mota e outros.
} 
àqueles portadores do vírus HIV, o acesso universal e igualitário à assistência farmacêutica e médico-hospitalar. O direito à saúde além de qualificar-se como direito fundamental que assiste a todas as pessoas - representa conseqüência constitucional indissociável do direito à vida. O Poder Público, qualquer que seja a esfera institucional de sua atuação no plano da organização federativa brasileira, não pode mostrar-se indiferente ao problema da saúde da população, sob pena de incidir, ainda que por censurável omissão, em grave comportamento inconstitucional;

b) A interpretação da norma programática não pode transformá-la em promessa constitucional inconseqüente: $\mathrm{O}$ caráter programático da regra inscrita no art. 196 da Carta Política — que tem por destinatários todos os entes políticos que compõem, no plano institucional, a organização federativa do Estado brasileiro — não pode converterse em promessa constitucional inconseqüente, sob pena de o Poder Público, fraudando justas expectativas nele depositadas pela coletividade, substituir, de maneira ilegítima, o cumprimento de seu impostergável dever, por um gesto irresponsável de infidelidade governamental ao que determina a própria Lei Fundamental do Estado;

c) Distribuição gratuita de medicamentos a pessoas carentes: O reconhecimento judicial da validade jurídica de programas de distribuição gratuita de medicamentos a pessoas carentes, inclusive àquelas portadoras do vírus HIV/AIDS, dá efetividade a preceitos fundamentais da Constituição da República (arts. 5º caput, e 196) e representa, na concreção do seu alcance, um gesto reverente e solidário de apreço à vida e à saúde das pessoas, especialmente daquelas que nada têm e nada possuem, a não ser a consciência de sua própria humanidade e de sua essencial dignidade.

Como se percebe com facilidade, o Ministro Celso de Mello inclinouse para uma decisão humanitária (que considera o direito fundamental à saúde), em contraposição a uma decisão orçamentária (que privilegiaria a liberdade do Poder Executivo em gerir os recursos públicos para definição da política pública de medicamentos). Na decisão acima relatada, o foco maior é a obrigação do Estado (todos os entes políticos que compõem, no plano institucional, a organização federativa do Estado brasileiro) em cumprir o espírito da norma constitucional (ainda que meramente

A\&C R. de Dir. Administrativo \& Constitucional, Belo Horizonte, ano 8, n. 33, p. 135-160, jul./set. 2008 
programática a norma do art. 196) de valorização dos direitos fundamentais à saúde e à própria vida, com respeito à dignidade da pessoa humana.

Atualmente, o STF considera "jurisprudência dominante" o entendimento favorável ao fornecimento de medicamentos aos indivíduos enfermos e necessitados, a tal ponto, que condenou, com base no art. 557, §2 do Código de Processo Civil, ${ }^{41}$ o Estado de Pernambuco a pagar ao cidadão uma multa processual, correspondente a $5 \%$ (cinco por cento) do valor corrigido da causa, por abuso do poder recursal (inconformismo sistemático). ${ }^{42}$

Por outro lado, a questão do "princípio da reserva do possível” já foi ventilada no STF, quando do julgamento da ADPF/45 (argüição de descumprimento de preceito fundamental). O Ministro Celso de Mello, em juízo monocrático, é bom dizer, após admitir que a formulação de políticas públicas é atribuição ordinária do Executivo e do Legislativo, afirmou entender que, embora excepcionalmente, ${ }^{43}$ tal incumbência poderá atribuir-se ao Poder Judiciário, se e quando os órgãos estatais competentes, por descumprirem os encargos político-jurídicos que sobre eles incidem, vierem a comprometer, com tal comportamento, a eficácia e a integridade de direitos individuais e/ou coletivos impregnados de estatura constitucional, ainda que derivados de cláusulas revestidas de conteúdo programático. Leiamos:

Não deixo de conferir, no entanto, assentadas tais premissas, significativo relevo ao tema pertinente à "reserva do possível" (STEPHEN HOLMES/CASS R. SUNSTEIN, "The Cost of Rights", 1999, Norton, New York), notadamente em sede de efetivação e implementação (sempre onerosas) dos direitos de segunda geração (direitos econômicos, sociais e culturais), cujo adimplemento, pelo Poder Público, impõe e exige, deste, prestações estatais positivas concretizadoras de tais prerrogativas individuais e/ou coletivas.

É que a realização dos direitos econômicos, sociais e culturais — além de caracterizar-se pela gradualidade de seu processo de concretização — depende,

\footnotetext{
${ }^{41}$ Reza o Código de Processo Civil: "Art. 557. O relator negará seguimento a recurso manifestamente inadmissível, improcedente, prejudicado ou em confronto com súmula ou com jurisprudência dominante do respectivo tribunal, do Supremo Tribunal Federal, ou de Tribunal Superior. $§ 1^{\circ}$-A Se a decisão recorrida estiver em manifesto confronto com súmula ou com jurisprudência dominante do Supremo Tribunal Federal, ou de Tribunal Superior, o relator poderá dar provimento ao recurso. $\S 1^{\circ}$ Da decisão caberá agravo, no prazo de cinco dias, ao órgão competente para o julgamento do recurso, e, se não houver retratação, o relator apresentará o processo em mesa, proferindo voto; provido o agravo, o recurso terá seguimento. $§ 2^{\circ}$ Quando manifestamente inadmissível ou infundado o agravo, o tribunal condenará o agravante a pagar ao agravado multa entre um e dez por cento do valor corrigido da causa, ficando a interposição de qualquer outro recurso condicionada ao depósito do respectivo valor". Nota: redação conforme Lei no 9.756, de 17.12.1998.

42 RE 534.908-Agr/PE. Julgamento em 11.12.2007. Publicação em 22.02.2008. Rel. Min. Cezar Peluso.

43 A excepcionalidade, a propósito, é mais comum do que parece. Grande número de ações judiciais envolvendo políticas públicas resvala para questões pertinentes a direitos fundamentais, de maneira que a intervenção judicial em políticas públicas é bastante significativa.
}

A\&C R. de Dir. Administrativo \& Constitucional, Belo Horizonte, ano 8, n. 33, p. 135-160, jul./set. 2008 
em grande medida, de um inescapável vínculo financeiro subordinado às possibilidades orçamentárias do Estado, de tal modo que, comprovada, objetivamente, a incapacidade econômico-financeira da pessoa estatal, desta não se poderá razoavelmente exigir, considerada a limitação material referida, a imediata efetivação do comando fundado no texto da Carta Política.

Não se mostrará lícito, no entanto, ao Poder Público, em tal hipótese mediante indevida manipulação de sua atividade financeira e/ou políticoadministrativa — criar obstáculo artificial que revele o ilegítimo, arbitrário e censurável propósito de fraudar, de frustrar e de inviabilizar o estabelecimento e a preservação, em favor da pessoa e dos cidadãos, de condições materiais mínimas de existência.

Cumpre advertir, desse modo, que a cláusula da "reserva do possível" ressalvada a ocorrência de justo motivo objetivamente aferível — não pode ser invocada, pelo Estado, com a finalidade de exonerar-se do cumprimento de suas obrigações constitucionais, notadamente quando, dessa conduta governamental negativa, puder resultar nulificação ou, até mesmo, aniquilação de direitos constitucionais impregnados de um sentido de essencial fundamentalidade. ${ }^{44}$

Desta maneira, a considerar-se o pensamento acima transcrito, só se admitiria invocação do princípio da reserva do possível mediante “ocorrência de justo motivo objetivamente aferível”, de maneira que o ente federado demandado a fornecer medicamentos a pessoa carente teria que, digamos assim, matematicamente demonstrar a impossibilidade financeira de atender, individualmente, ao pleito do autor da ação processual.

\section{Haveria como ser diferente?}

Os julgados acima foram trazidos à colação para fins de análise no presente texto do poder do juiz em mover-se no ordenamento jurídico para fundamentar a decisão da maneira que pretender. Chamaremos a isso de espaço interpretativo razoavelmente ajustável. Bourdieu escreve que "Não é raro, decerto, que o direito, instrumento dócil, adaptável, flexível, polimorfo, seja de facto chamado a contribuir para racionalizar ex post decisões em que não teve qualquer participação". ${ }^{45}$

O que se verifica, na análise da jurisprudência acima, é que os juízes decidiram (quase em bloco) que em matéria de direitos fundamentais poderiam interferir nas políticas públicas, porque: 1) estão aplicando a Constituição; 2) o Executivo se submete à Constituição. Ou seja, não é o Judiciário que interfere nas políticas públicas do Executivo; ao revés, o

\footnotetext{
${ }^{44}$ Disponível em: <www.stf.gov.br>. Acesso em: $1^{\circ}$ jun. 2008.

45 BOURDIEU. O poder simbólico, p. 223-224.
}

A\&C R. de Dir. Administrativo \& Constitucional, Belo Horizonte, ano 8, n. 33, p. 135-160, jul./set. 2008 
Executivo é que não cumpre a Constituição. Assim, o Judiciário legitima sua intervenção.

A questão é: os juízes adequaram o discurso para dizer que isso não representaria ofensa ao princípio da separação dos poderes, ou realmente deduziram tal conclusão do ordenamento jurídico a partir de mera interpretação dos textos legais?

Essa pergunta nos remete à questão política da decisão judicial. No caso em estudo (intervenção judicial em políticas públicas), entendemos que a escolha da decisão a tomar é eminentemente política, dado que também caberia uma outra fundamentação: a de que embora a Constituição consagre direitos fundamentais, a sua execução por políticas públicas se dá conforme critérios discricionários do Executivo, em razão da separação de poderes prevista no próprio art. $2^{\circ}$ da Constituição. E por que não é esta a decisão e fundamentação? Porque a teoria jurídica responde com um caminho possível ao Judiciário: o princípio da máxima efetividade da Constituição, e os demais estudados acima.

Dá-se, então, que os teóricos (doutrinadores) servem aos práticos (juízes), numa verdadeira cumplicidade, que faz aflorar a percepção de construção do campo jurídico, que acaba por se sobrepor a outros campos, como o próprio campo político. Talvez seja isso o que Bourdieu quer dizer quando escreve que:

\begin{abstract}
As diferentes categorias de intérpretes autorizados tendem sempre a distribuirse entre dois pólos extremos: de um lado, a interpretação voltada para a elaboração puramente teórica da doutrina, monopólio dos professores que estão encarregados de ensinar, em forma normalizada e formalizada, as regras em vigor; do outro lado, a interpretação voltada para a avaliação prática de um caso particular, apanágio de magistrados que realizam actos de jurisprudência e que podem, deste modo, - pelo menos alguns deles contribuir também para a construção jurídica. ${ }^{46}$
\end{abstract}

Ou seja, Bourdieu alega que o campo jurídico tem dois tipos de categorias de intérpretes: teóricos (professores, que no Brasil poderíamos chamar de “doutrinadores”) e, digamos assim, práticos (juízes), mas identifica a possibilidade de que ambas as categorias se complementem.

A análise da jurisprudência feita neste trabalho demonstra claramente a influência do princípio da máxima efetivação da Constituição (campo teórico) nas decisões judiciais de controle de políticas públicas, havendo

\footnotetext{
${ }^{46}$ BOURDIEU. O poder simbólico, p. 217.
}

A\&C R. de Dir. Administrativo \& Constitucional, Belo Horizonte, ano 8, n. 33, p. 135-160, jul./set. 2008 
evidente conciliação entre doutrinadores e magistrados. Evidentemente, a jurisprudência, principalmente do STF e STJ, alimenta, em feedback, os livros de doutrina, que passam a proclamar para advogados e estudantes a corrente jurisprudencial dominante.

Assim, muito do que foi escrito por Bourdieu se verifica, realmente, no campo jurídico, principalmente no tocante à liberdade dos juízes em interpretar as normas jurídicas dentro de um espaço razoavelmente livre.

No entanto, a primeira questão que propomos é: haveria como ser diferente? Pensamos que não. A idéia do juiz distante, neutro e dotado de enorme sabedoria, a ponto de nunca errar, perde-se nos corredores da história e torna-se cada vez mais ultrapassada. Os juízes, ao menos no Brasil, parecem cada vez mais demonstrar o lado político (não partidário) de sua atuação. Exemplo notável é a veiculação dos julgamentos do Supremo Tribunal Federal pela televisão, em rede nacional, através da TV Justiça. Ora, tal exposição faz com que a sociedade possa analisar a fundo o modo e as razões de decidir dos ministros do STF, o que significa dizer que os juízes do tempo atual não estão preocupados em esconder a maneira de pensar: muito pelo contrário, querem ser influentes na sociedade.

Entendemos que Bourdieu, ao constatar um grau de liberdade dos juízes em decidir, está correto. No entanto, pela análise de jurisprudência que aqui fizemos, percebe-se que existe um limite a tal liberdade, um parâmetro (que o próprio Judiciário se impõe), que é a Constituição, ainda que venham, eventualmente, a desconsiderar todo o resto.

A propósito, entendemos pertinente informar que advogamos a tese de que juízes "engessados" e obrigados à interpretação e aplicação literal da lei jamais conseguiriam cumprir seu papel democrático de realização dos direitos fundamentais dos indivíduos, e seriam reféns do legislador (figura na qual se inclui o próprio Chefe do Poder Executivo, ao editar medidas provisórias). Assim, se o Judiciário é refém das normas ditadas pelo Legislativo e pelo Executivo, como se haveria de falar em checks and balances?

A teoria contemporânea da separação de poderes não subsiste a não ser com um Judiciário independente, forte (inclusive politicamente), e que busca a interpretação sistêmica do Direito. Ou seja, pouca importância possui o texto da lei; importa o contexto (dentro do ordenamento jurídico) em que se insere a lei. Nesse sentido, o compromisso maior do juiz deve ser com o espírito da ordem constitucional (em nosso entender).

A\&C R. de Dir. Administrativo \& Constitucional, Belo Horizonte, ano 8, n. 33, p. 135-160, jul./set. 2008 
Oriana Piske de Azevedo Magalhães Pinto, Juíza de Direito do Tribunal de Justiça do Distrito Federal e Territórios, bem discorreu sobre a questão da liberdade dos juízes e o cumprimento de sua função social:

A passagem do Estado Liberal para o Estado Social modificou as relações entre o Poder Legislativo e o Poder Executivo, desenvolvendo uma postura mais ativa, na prestação de serviços públicos, em oposição ao Estado ausente, liberalista. Este fato explica o aumento da competência normativa e da área de autonomia do Poder Executivo, a quem a lei concedeu maior discricionariedade. O uso abusivo de tal ampliação da autonomia daqueles Poderes e a ofensa aos direitos fundamentais, no Estado Social, levaram a uma reação do Poder Judiciário contra os abusos dos administradores e dos legisladores.

Foi o crescimento e diversificação das necessidades da sociedade no tocante à regulação legislativa que tornou insustentável o seu monopólio parlamentar; por conseguinte a partilha da competência legislativa com o Executivo vai implicar a extensão das competências próprias do órgão de controle da lei — o poder Judicial. Assim, abandona-se a crença na auto-suficiência de um processo lógico-dedutivo que reduzira a interpretação a uma exegese do texto, e passa-se destacar a importância decisiva da applicatio pela qual todo o ato de interpretação constitui um aditamento de sentido.

As alterações produzidas no exercício da função jurisdicional não só denunciam um crescimento inédito da sua influência social como, decididamente, arrancam os juízes do elenco de figurantes do Estado moderno, atribuindo-lhes um protagonismo a que, relutantes, acabaram por aceder.

(...)

O Juiz, no nosso sistema judicial, sem extrapolar o marco jurídico-constitucional, pode e deve desempenhar sua tarefa de dirimir litígios de modo socialmente mais justo cumprindo papel inteiramente distinto do juiz legalistapositivista, criado pela Revolução Francesa para ser la bouche de la loi ${ }^{47}$

Não se admite mais o juiz escravo da letra da lei!

\section{Breve diálogo entre Bourdieu e Kelsen}

Como o comportamento dos juízes se dá dentro da previsão kelseniana? A pergunta é cabível, porque Bourdieu, logo no início do capítulo "A força do direito", diz o seguinte:

(...) A reivindicação da autonomia absoluta do pensamento e da acção jurídicos afirma-se na constituição em teoria de um modo de pensamento específico, totalmente liberto do peso social, e a tentativa de Kelsen para criar uma "teoria pura do direito" não passa do limite ultra-consequente do esforço

\footnotetext{
47 PINTO. A atuação criativa do juiz, p. 2-18. Disponível no site do Instituto de Direito Comparado e Internacional de Brasília. <http://www.idcb.org.br>. Acesso em: $1^{\circ}$ jun. 2008.
}

A\&C R. de Dir. Administrativo \& Constitucional, Belo Horizonte, ano 8, n. 33, p. 135-160, jul./set. 2008 
de todo ocorpo dos juristas para construir um corpo de doutrinas e de regras completamente independentes dos constrangimentos e das pressões sociais, tendo nele mesmo o seu próprio fundamento. ${ }^{48}$

A segunda questão que queremos propor é: a criação de um sistema fechado por Kelsen realmente ignora o campo político das decisões judiciais? Em sua obra Teoria pura do Direito, ${ }^{49}$ Kelsen abre um capítulo específico à hermenêutica jurídica (cap. 8). Lá escreve que, quando o Direito é aplicado por um órgão jurídico, este necessita de fixar o sentido das normas que vai aplicar, isto é, tem de interpretar estas normas. Para Kelsen, a interpretação é uma operação mental que acompanha o processo da aplicação do Direito no seu progredir de um escalão superior para um escalão inferior. Na hipótese em que geralmente se pensa quando se fala de interpretação, na hipótese da interpretação da lei, deve responder-se à questão de saber qual o conteúdo que se há de dar à norma individual de uma sentença judicial ou de uma resolução administrativa, norma essa a deduzir da norma geral da lei na sua aplicação a um caso concreto. Mas há também uma interpretação da Constituição, na medida em que de igual modo se trate de aplicar esta - no processo legislativo, ao editar decretos ou outros atos constitucionalmente imediatos - a um escalão inferior; e uma interpretação dos tratados internacionais ou das normas do Direito internacional geral consuetudinário, quando estas e aqueles têm de ser aplicados, num caso concreto, por um governo ou por um tribunal ou órgão administrativo, internacional ou nacional. E há igualmente uma interpretação de normas individuais, de sentenças judiciais, de ordens administrativas, de negócios jurídicos, etc., em suma, de todas as normas jurídicas, na medida em que hajam de ser aplicadas. Mas também os indivíduos, que têm - não de aplicar, mas - de observar o Direito, observando ou praticando a conduta que evita a sanção, precisam de compreender e, portanto, de determinar o sentido das normas jurídicas que por eles hão de ser observadas. E, finalmente, também a ciência jurídica, quando descreve um Direito positivo, tem de interpretar suas normas.

Desta forma, em Kelsen, existem duas espécies de interpretação: a interpretação do Direito pelo órgão que o aplica, e a interpretação do Direito que não é realizada por um órgão jurídico, mas por uma pessoa privada e, especialmente, pela ciência jurídica.

\footnotetext{
48 BOURDIEU. O poder simbólico, p. 209.

${ }^{49}$ As idéias atribuídas a Hans Kelsen neste tópico estão contidas em: Teoria pura do direito, p. 387-397.
}

A\&C R. de Dir. Administrativo \& Constitucional, Belo Horizonte, ano 8, n. 33, p. 135-160, jul./set. 2008 
Entende ele que a norma do escalão superior regula o ato através do qual é produzida a norma do escalão inferior. A norma do escalão superior é uma espécie de quadro ou moldura a ser preenchida pelo ato, dentro de uma margem de liberdade aceitável. Dessa liberdade resulta que todo o ato jurídico em que o Direito é aplicado, quer seja um ato de criação jurídica, quer seja um ato de pura execução, é, em parte, determinado pelo Direito, e, em parte, indeterminado. A indeterminação pode ser intencional. Porém, também existe a indeterminação não-intencional do ato de aplicação do Direito, por pluralidade de significações. Em todos esses casos de indeterminação, intencional ou não, do escalão inferior, oferecem-se várias possibilidades à aplicação jurídica. E escreve Kelsen:

O Direito a aplicar forma, em todas estas hipóteses, uma moldura dentro da qual existem várias possibilidades de aplicação, pelo que é conforme ao Direito todo ato que se mantenha dentro deste quadro ou moldura, que preencha esta moldura em qualquer sentido possível.

Se por "interpretação" se entende a fixação por via cognoscitiva do sentido do objeto a interpretar, o resultado de uma interpretação jurídica somente pode ser a fixação da moldura que representa o Direito a interpretar e, consequentemente, o conhecimento das várias possibilidades que dentro desta moldura existem. Sendo assim, a interpretação de uma lei não deve necessariamente conduzir a uma única solução como sendo a única correta, mas possivelmente a várias soluçóes que — na medida em que apenas sejam aferidas pela lei a aplicar - têm igual valor, se bem que apenas uma delas se torne Direito positivo no ato do órgão aplicador do Direito - no ato do tribunal, especialmente. Dizer que uma sentença judicial é fundada na lei, não significa, na verdade, senão que ela se contém dentro da moldura ou quadro que a lei representa. ${ }^{50}$

Percebe-se claramente, portanto, que a Teoria Pura do Direito não ignora a liberdade do juiz em interpretar o Direito e aplicá-lo de diversas formas corretamente possíveis. Kelsen, em seguida, ao abordar os chamados métodos de interpretação, diz que todos os métodos de interpretação até então elaborados (época em que escrita sua obra) conduzem sempre a um resultado apenas possível, nunca a um resultado que seja o único correto.

Assim, podemos, com certa tranqüilidade, ousar dizer que Bourdieu e Kelsen concordam quanto a um ponto: a liberdade interpretativadecisória dos juízes. Textualmente, Kelsen diz o seguinte:

Na aplicação do Direito por um órgão jurídico, a interpretação cognoscitiva (obtida por uma operação de conhecimento) do Direito a aplicar combina-se

${ }^{50}$ KELSEN. Teoria pura do direito, p. 390-391.

A\&C R. de Dir. Administrativo \& Constitucional, Belo Horizonte, ano 8, n. 33, p. 135-160, jul./set. 2008 
com um ato de vontade em que o órgão aplicador do Direito efetua uma escolha entre as possibilidades reveladas através daquela mesma interpretação cognoscitiva. ${ }^{51}$

Ora, claramente Kelsen admite um ato de vontade do juiz ao aplicar o Direito, ao escolher uma determinada interpretação e rejeitar outra(s).

Por outro lado, a visão que Kelsen exerce em relação aos teóricos (professores/doutrinadores) em nada difere (em nossa opinião) da posição de Bourdieu quando diz que existe no Direito um "espaço dos possíveis". ${ }^{52}$ Kelsen também afirma o mesmo, quando escreve que "A interpretação jurídico-científica não pode fazer outra coisa senão estabelecer as possíveis significações de uma norma jurídica". ${ }^{53}$

E qual a diferença entre Bourdieu e Kelsen? Há várias, mas destacamos uma em especial: o objeto de estudo! A intenção de Bourdieu, ao escrever o capítulo 8 da obra $O$ poder simbólico está clara logo no início, no subtítulo. Veja-se: "A força do direito: elementos para uma sociologia do campo jurídico" ${ }^{54}$ Em Kelsen, o ato de vontade do juiz, a escolha de qual Direito aplicar, é escolha política, que não é objeto de estudo da ciência jurídica. Conforme as próprias palavras de Kelsen, a decisão a se escolher "não é um problema de teoria do Direito, mas um problema de política do Direito". ${ }^{55}$ Poderíamos acrescentar: um problema da sociologia do campo jurídico, como quer Bourdieu. Já na primeira página de sua obra, Kelsen escreve:

A Teoria Pura do Direito é uma teoria do Direito positivo — do Direito positivo em geral, não de uma ordem jurídica especial. É teoria geral do Direito, (...).

Como teoria, quer única e exclusivamente conhecer o seu próprio objeto. Procura responder a esta questão: o que é e como é o Direito? Mas já não lhe importa a questão de saber como deve ser o Direito, ou como deve ele ser feito. É ciência jurídica e não política do Direito.

Quando a si própria se designa como "pura" teoria do Direito, isto significa que ela se propõe garantir um conhecimento apenas dirigido ao Direito e excluir deste conhecimento tudo quanto não pertença ao seu objeto, tudo quanto não se possa, rigorosamente, determinar como Direito. Quer isto dizer que ela pretende libertar a ciência jurídica de todos os elementos que lhe são estranhos. Esse é o seu princípio metodológico fundamental. ${ }^{56}$

\footnotetext{
51 KELSEN. Teoria pura do direito, p. 394.

52 BOURDIEU. O poder simbólico, p. 211.

53 KELSEN. Teoria pura do direito, p. 395. Grifo nosso.

54 BOURDIEU. O poder simbólico, p. 209. Grifo nosso.

55 KELSEN. Teoria pura do direito, p. 393.

56 KELSEN. Teoria pura do direito, p. 1.
}

A\&C R. de Dir. Administrativo \& Constitucional, Belo Horizonte, ano 8, n. 33, p. 135-160, jul./set. 2008 
Assim, não é correto, pensamos, sob uma perspectiva da teoria do campo jurídico de Bourdieu, afirmar que os juristas se consideram imersos num regime jurídico fechado, como se ausentes do mundo. A questão é outra, própria ao foco jurídico: muito embora Kelsen tenha enxergado a existência de um objeto de estudo para a "política do Direito" (que Bourdieu chamaria de "relações de força existentes"), ${ }^{57}$ preocupou-se em estabelecer as diretrizes de uma "ciência jurídica". Kelsen apenas separou os objetos de estudo, deixando questões não jurídicas à sociologia, isca muito bem degustada por Bourdieu, que aliás, disseca, com enorme competência, o campo jurídico, porém do ponto de vista sociológico e, por via de conseqüência, não-kelseniano.

\section{Conclusão}

Escrevemos o presente texto para cumprir os seguintes objetivos:

$1^{\circ}$ ) demonstrar que Bourdieu está correto quando:

(i) afirma existir um campo jurídico que divide as pessoas entre profanos e profissionais, e que estes disputam no espaço judicial;

(ii) entende que os juízes gozam de ampla liberdade de decidir;

(iii) entende o direito como manifestação do poder simbólico.

$2^{\circ}$ ) para dizer que:

(i) não haveria como ser diferente, num país que se pretende democrático: direitos fundamentais foram outorgados pela Assembléia Nacional Constituinte, e o titular do poder constituinte é o povo, razão pela qual a efetivação de direitos fundamentais pelo Judiciário encontra guarida democrática, não se podendo acusar de ilegítimas as decisões judiciais sobre políticas públicas apenas porque membros do Executivo e Legislativo são eleitos pelo povo;

(ii) o espaço interpretativo razoavelmente ajustável, em nossa denominação, já estava previsto por Hans Kelsen na Teoria Pura do Direito, quando falou das molduras ou quadros;

(iii) a escolha da interpretação possível a ser adotada na aplicação do Direito no caso concreto, em Kelsen, é objeto de estudo da política do Direito, tendo havido uma clara opção metodológica na obra kelseniana.

\footnotetext{
${ }^{57}$ BOURDIEU. O poder simbólico, p. 210.
}

A\&C R. de Dir. Administrativo \& Constitucional, Belo Horizonte, ano 8, n. 33, p. 135-160, jul./set. 2008 
Resumen: El artículo aborda decisiones judiciales brasileñas sobre políticas públicas, la "Teoría del Campo Jurídico", de Pierre Bourdieu, y la "Teoría Pura del Derecho", de Hans Kelsen, para un análisis final sobre la libertad que tienen los jueces en la interpretación y aplicación de las normas jurídicas.

Palabras clave: Campo jurídico. Teoría Pura del Derecho. Libertad de interpretación y aplicación de normas jurídicas. Intervención judicial en políticas públicas.

\section{Referências}

BARROS, Marcus Aurélio de Freitas. Miradas sobre o controle jurisdicional de políticas públicas: dos precedentes judiciais à teoria. Disponível em: <http://sisnet.aduaneiras. com.br/lex/doutrinas/arquivos/miradas.pdf > . Acesso em: $1^{\circ}$ jun. 2008.

BELO, Fábio; LASMAR, Gabriela; RODRIGUES, Pedro Paulo. O inacessível campo jurídico: breve leitura de o processo, de Kafka, a partir da teoria de Pierre Bourdieu. Disponível em: <http://conpedi.org/manaus>. Acesso em: $1^{\circ}$ jun. 2008.

BORGES, Marcos Afonso. Jurisdição voluntária. Direito Processual Civil. Conferências. Revista de Processo, São Paulo, v. 11-12, p. 209-219, jul./dez. 1978.

BOURDIEU, Pierre. O poder simbólico. 8. ed. Tradução Fernando Tomaz (português de Portugal). Rio de Janeiro: Bertrand Brasil, 2005.

CANOTILHO, J. J. Gomes. Direito constitucional. 5. ed. Coimbra: Almedina, 1991.

CARNEIRO, Athos Gusmão. Jurisdição e competência. 11. ed. São Paulo: Saraiva, 2001.

CARVALHO, Kildare Gonçalves. Direito constitucional: teoria do Estado e da Constituição. 10. ed. Belo Horizonte: Del Rey, 2004.

GIL, William Jiménez. La teoria del campo juridico de Pierre Bourdieu: aplicación a un caso practico del Derecho Colombiano. Disponível em: <http://www.docentes.unal.edu.co/ wjimenezg/>. Acesso em: $1^{\circ}$ jun. 2008.

KAFKA, Franz. O processo. São Paulo: Martin Claret, 2002. [cap. VII: O advogado. O fabricante. O pintor].

KELSEN, Hans. Teoria pura do direito. 5. ed. São Paulo: Martins Fontes, 1996.

LIMA, Alcides de Mendonça. Jurisdição voluntária. Doutrina nacional. Direito processual Civil. Revista de Processo, São Paulo, v. 17, p. 25-40.

MORAES, Guilherme Peña. Direito constitucional: teoria da Constituição. 2. ed. Rio de Janeiro: Lumen Juris, 2004.

PINTO, Oriana Piske de Azevedo Magalhães. A atuação criativa do juiz, p. 2-18. Disponível no site do Instituto de Direito Comparado e Internacional de Brasília: <http:// www.idcb.org.br>. Acesso em: $1^{\circ}$ jun. 2008.

SILVA, Ovídio Baptista da. Curso de processo civil. 2. ed. Porto Alegre: Fabris, 1991. v. 1.

THEODORO JÚNIOR, Humberto. Curso de direito processual civil. Rio de Janeiro: Forense, 1995 .

A\&C R. de Dir. Administrativo \& Constitucional, Belo Horizonte, ano 8, n. 33, p. 135-160, jul./set. 2008 
THIRY-CHERQUES, Hermano Roberto. Pierre Bourdieu: a teoria na prática. RAP, Rio de Janeiro, v. 40, n. 1, p. 27-55, jan./fev. 2006. Disponível em: < http://www.scielo.br/pdf/ rap/v40n1/v40n1a03.pdf>. Acesso em: 12 jun. 2008.

Informação bibliográfica deste texto, conforme a NBR 6023:2002 da Associação Brasileira de Normas Técnicas (ABNT):

ARAÚjo, Thiago Cássio d'Ávila. O juiz em Pierre Bourdieu, o controle jurisdicional de políticas públicas no Brasil e a questão da liberdade de interpretação das normas jurídicas. A\&C Revista de Direito Administrativo \& Constitucional, Belo Horizonte, ano 8, n. 33, p. $135-160$, jul./set. 2008. 